\title{
ANALISIS EMPIRICAL ORTHOGONAL FUNCTION (EOF) BERBASIS EIGEN VALUE PROBLEM (EVP) PADA DATASET SUHU PERMUKAAN LAUT INDONESIA
}

\author{
S. M. ROBIAL ${ }^{1}$, S. NURDIATI ${ }^{2}$, A. SOPAHELUWAKAN ${ }^{3}$
}

\begin{abstract}
Abstrak
Data global Suhu Permukaan Laut (SPL) hasil observasi dari tahun ke tahun dibatasi penggunaannya untuk menentukan variasi spasial dan temporal. Analisis dilakukan terhadap data SPL di wilayah perairan Indonesia selama 600 bulan. Metode yang digunakan untuk analisis tersebut adalah metode Empirical Orthogonal Function (EOF) berbasis Eigen Value Problem (EVP). Metode ini lebih dikenal sebagai metode Principal Component Analysis (PCA). Metode EOF bertujuan mereduksi data yang berukuran besar menjadi beberapa mode tanpa menghilangkan informasi dari data yang diamati. Analisis dengan metode tersebut menghasilkan empat komponen utama terbesar yang diinisialkan dengan mode EOF1, EOF2, EOF3 dan EOF4. Mode EOF1 menjelaskan 51.4\% dari variasi total dan merupakan pola dominan yang mewakili hampir seluruh data. Mode EOF2 menunjukkan $26.7 \%$ dari variasi total. Mode EOF3 dan EOF4 masing-masing menjelaskan $11.2 \%$ dan $4.9 \%$ dari variasi total. Setiap mode EOF mengandung koefisien yang memuat variabel berupa data grid dan vektor eigen. Data grid menggambarkan letak geografis dan vektor eigen menggambarkan dimensi ruang. Efektifitas dari empat mode EOF yang dihasilkan tersebut dipertahankan untuk dapat menghampiri data asli. Hampiran data asli diperoleh dengan menentukan nilai norm error dari hasil reduksi menggunakan teknik error norm matriks. Teknik ini menghasilkan pola hubungan antara tingkat kesalahan relatif (relative error) dan mode EOF. Pola hubungan yang diperoleh memperlihatkan bahwa semakin banyak mode yang diambil, maka kesalahan relatif akan semakin kecil.
\end{abstract}

Kata Kunci: empirical orthogonal function, eigen value problem, analisis komponen utama, suhu permukaan laut

\section{PENDAHULUAN}

Indonesia merupakan negara maritim dengan dua pertiga wilayahnya adalah lautan. Jika dilihat dari posisi geografisnya Indonesia berada pada garis khatulistiwa dan terletak di antara dua samudera yaitu samudera Pasifik dan

\footnotetext{
${ }^{1}$ Mahasiswa Program Pascasarjana, Program Studi Matematika Terapan, Sekolah Pascasarjana IPB Dramaga Bogor, 16680. E-mail: sitimr25@gmail.com

${ }^{2}$ Departemen Matematika, Fakultas Matematika dan Ilmu Pengetahuan Alam, Jalan Meranti Kampus IPB Dramaga Bogor, 16680. E-mail: nurdiati@ipb.ac.id

${ }^{3}$ Badan Meteorologi, Klimatologi dan Geofisika (BMKG), Jalan Angkasa 1 No.2, Kemayoran, Jakarta 10720.

E-mail: ardhasena@bmkg.go.id
} 
samudera Hindia. Oleh karena itu, Indonesia beriklim tropis dengan dua musim yaitu musim hujan dan musim kemarau. Daerah-daerah tropis tersebut mempunyai pengaruh kuat dalam menentukan hubungan antara atmosfer dan lautan. Hubungan ini merupakan sebuah konsep dinamika iklim penting untuk memahami informasi perubahan cuaca. Laut mempunyai peranan penting dalam proses perubahan iklim baik dalam wilayah regional maupun global. Salah satu parameter yang memberikan pengaruh besar dalam proses tersebut adalah Suhu Permukaan Laut (SPL).

Penelitian terkait data SPL pernah dilakukan sebelumnya dengan lokasi dan rentang waktu yang berbeda-beda. Nicholls (1984) dalam penelitiannya menyatakan bahwa hubungan antara laut dan udara di wilayah Indonesia bergantung pada anomali SPL yang mempunyai hubungan seasonal kuat dengan samudera Pasifik. Saji et al. (1999) dalam penemuannya menjelaskan bahwa anomali SPL di samudera Hindia mempunyai pengaruh yang kuat dengan hujan di Indonesia. Nezlin \& Williams (2003) menganalisis anomali SPL dari data satelit dengan metode EOF untuk memeriksa fitur kejadian El-nino pada tahun 19971998 dan hasilnya menjelaskan bahwa bagian tengah dan selatan California teleconnection terhadap kejadian El-nino. Storch dan Zwiers [1] mendefinisikan Principle Component Analysis (PCA) sebagai Empirical Orthogonal Function (EOF). Vektor eigen yang mendefinisikan PCA disebut sebagai variabel time series dan nilai-nilai dari PCA disebut sebagai variabel EOF. Berdasarkan penelitian terkait di atas, maka dalam penelitian ini data SPL Indonesia selama 600 bulan akan dianalisis menggunakan metode Empirical Ortogonal Function (EOF) berbasis Eigen Value Problem (EVP). Metode ini bertujuan untuk mereduksi sekumpulan data SPL yang berukuran besar menjadi beberapa mode EOF tanpa menghilangkan informasi dari data asli. Hal ini dapat dicapai dengan membentuk satu set variabel baru yang disusun dengan menggunakan prinsip komponen utama yang tidak berkorelasi. Hal ini berarti sebagian persamaan EOF menyimpan sebagian besar varians yang ada pada variabel asli.

Berbeda dengan penelitian sebelumnya yang mengkaji kejadian tertentu seperti kejadian anomali dan El-nino, maka dalam penelitian ini akan dikaji khusus data SPL dengan cakupan wilayah Indonesia dalam rentang waktu 600 bulan. Hasil yang diperoleh akan sangat berguna untuk mengetahui karakteristik dari SPL sebagai suatu informasi dalam memprediksi iklim untuk jangka panjang dan cuaca untuk jangka pendek. Secara umum metode EOF berbasis EVP bekerja sangat baik dengan menghasilkan beberapa varians yang menggambarkan seluruh data. Oleh sebab itu, bisa dikatakan bahwa hasil reduksi dapat dijadikan sebagai suatu aproksimasi dalam menentukan nilai kesalahan atau norm error. Nilai kesalahan ini dihitung untuk mengetahui seberapa besar hampiran hasil reduksi (mode EOF) terhadap data asli. Hal ini dapat dapat dihitung dengan menggunakan teknik error norm matriks. Hasil yang diperoleh dari teknik ini adalah besar hampiran berupa nilai norm error. Hasil tersebut menggambarkan pola hubungan antara tingkat kesalahan relatif (relative error) dan mode EOF. Pola hubungan ini memperlihatkan bahwa semakin banyak mode EOF yang diambil, maka tingkat 
kesalahan relatif semakin kecil.

\section{METODE EMPIRICAL ORTHOGONAL FUNCTION (EOF)}

\subsection{Matriks Data}

Misalnya grid dataset disajikan dalam matriks kolom tiga dimensi. Grid tersebut terdiri atas array dari ruang dan waktu $X(t, s)$ yang mewakili bidang $F$ pada waktu $t$ dan ruang $s$. Nilai dari bidang pada waktu diskret $t_{i}$ dan titik grid $s_{j}$ ditulis $x_{i j}$ untuk $i=1, \ldots, n$ dan $j=1, \ldots, p=p_{1} p_{2}$. Hannachi [2] membentuk bidang yang diamati mewakili data matriks sebagai berikut:

$$
X(t, s)=\left(\begin{array}{cccc}
x_{11} & x_{12} & \cdots & x_{1 p} \\
x_{21} & x_{22} & \cdots & x_{2 p} \\
\vdots & \vdots & \ddots & \vdots \\
x_{n 1} & x_{n 2} & \cdots & x_{n p}
\end{array}\right)
$$

\subsection{Analisis Empirical Orthogonal Function (EOF) berbasis Eigen value Problem EVP}

EOF merupakan suatu metode untuk menentukan pola-pola dominan yang ditentukan oleh data dan berevolusi dalam ruang dan waktu. Jolliffe [3] memaparkan tujuan utama dari analisis EOF adalah mereduksi sejumlah besar variabel data menjadi hanya beberapa variabel tanpa mengubah sebagian besar varians dari data asli. Analisis EOF dimulai dengan menentukan matriks kovarians dari matriks data SPL yang sudah tersusun, yaitu:

$$
\Sigma=\frac{1}{n-1} X^{T} X
$$

Matriks kovarians $\Sigma$ pada persamaan (1) merupakan matriks simetris real yang memiliki vektor eigen $e_{m}(x, y)$ dan nilai eigen positif $\lambda_{m}$. Dengan menggunakan EVP diperoleh formula berikut:

$$
R e_{m}=\lambda_{m} e_{m} .
$$

Dari persamaan (2) diperoleh nilai eigen $\lambda$ dan vektor eigen $e$ yang memenuhi persamaan $|R-\lambda I|=0$ dan $(R-\lambda I) e=0$. Vektor eigen $e_{m}(x, y)$ merupakan variabilitas temporal EOF yang ortogonal, sehingga memenuhi persamaan:

$$
\sum_{x, y=1}^{N} e_{m}\left(x_{i}, y_{i}\right) e_{n}\left(x_{i}, y_{i}\right)=0, m \neq n \text {. }
$$

Variabilitias temporal EOF pada persamaan (3) dibentuk untuk memperoleh persamaan baru. Persamaan baru tersebut merupakan variabilitas 
spasial $u_{m}(t)$ yang diperoleh dengan memproyeksikan data asli pada variabilitas temporal. Singleton [4] mendefinisikannya sebagai perkalian antara vektor eigen $e_{m}(x, y)$ dengan matriks data awal $X(s, t)$ yaitu:

$$
u_{m}(t)=\sum_{x, y=1}^{N} X(x, y, t) e_{m}(x, y) \text {. }
$$

Varians yang dapat dijelaskan oleh variabel baru ke- $m$ pada persamaan (4) bergantung pada persentase kontribusi $p_{m}$ dari masing-masing nilai eigen. Navarra [5] menghitung varians tersebut dengan rumus:

$$
p_{m}=\frac{\lambda_{m}}{\sum_{n=1}^{N} \lambda_{n}}
$$

Tahapan analisis metode EOF terhadap data SPL secara khusus akan disajikan dalam algoritme 2.1 di bawah ini.

\section{Algoritme 2.1 Analisis Empirical Orthogonal Function (EOF)}

1. Extracting matriks data $R$ berukuran $m \times n$ menjadi suatu matriks data $X$.

2. Pembentukan matriks kovarians $\sum$.

3. Penentuan nilai eigen dan vektor eigen yang bersesuaian dari matriks kovarians $\sum$ dengan persamaan karakteristik $\left|\sum-\lambda I\right|=0$.

4. Penentuan mode $U_{m}(t)$ dengan $t=1,2, \ldots, m$ berdasarkan persamaan (4).

5. Penentuan proporsi varians dari $m$ EOF berdasarkan persamaan (5).

6. Analisis data secara spasial dan temporal.

7. Perhitungan error norm matriks.

\section{NILAI ERROR DAN NORM}

Salah satu alasan penggunaan norm adalah karena hal tersebut memberi cara ringkas tentang ukuran kesalahan dan gangguan (perturbations). Sebelum diberikan contoh, akan dilihat beberapa definisi dasar. Misalkan $\alpha$ dan $\hat{\alpha}$ adalah skalar dengan $\alpha \approx \hat{\alpha}$. Kesalahan absolut (absolute error) $\hat{\alpha}$ sebagai aproksimasi untuk $\alpha$ dengan formula $|\alpha-\hat{\alpha}|$. Dalam beberapa kasus, akan dilihat hal tersebut sebagai nilai error (kesalahan absolut). Namun, kesalahan absolut sulit untuk diinterpretasikan pada konteks data atau variabel yang cukup besar. Oleh karena itu, untuk alasan ini digunakan nilai error yang berdimensi kecil yaitu kesalahan relatif (relative error) dengan formula dari absolute error $\frac{|\alpha-\hat{\alpha}|}{|\alpha|}$ [6].

Berdasarkan definisi dasar di atas, untuk menentukan ukuran kesalahan dari vektor dan matriks digunakan aturan norm. Dalam penelitian ini, nilai error yang 
ingin diperoleh berasal dari suatu matriks data asli. Oleh karena itu, aturan norm yang digunakan adalah norm matriks, sehingga dalam menentukan nilai error perlu digunakan teknik error norm matriks.

\subsection{Norm Matriks}

Fungsi $f: R^{n \times p} \rightarrow R$ disebut norm matriks (matrix norm) jika untuk setiap $A, B \in R^{n \times p}$ dan $\alpha \in R$ memenuhi ketiga aksioma berikut:

1. $f(A) \geq 0$ dan $f(A)=0 \leftrightarrow A=0$.

2. $f(A+B) \leq f(A)+f(B)$.

3. $f(\alpha A)=|\alpha| f(A)$.

Dalam hal ini, untuk memudahkan penulisan, norm matriks $A$ ditulis $\|A\|$ sehingga $\|A\|=f(A)[7]$.

\subsection{Error Norm Matriks}

Teknik error norm matriks yang akan digunakan dalam penelitian ini bertujuan untuk melihat efektifitas atau kualitas dari hasil reduksi (mode EOF). Hal ini berarti, seberapa besar hampiran mode EOF mampu mewakili data sebenarnya. Hampiran tersebut dapat dilihat dari perolehan nilai norm error. Nilai error ini diperlihatkan dengan membentuk pola hubungan antara tingkat kesalahan dan mode EOF. Berdasarkan teknik tersebut error norm absolut akan dibentuk dengan formula Golub \& Loan [8], yaitu:

$$
\|A-\hat{A}\|=\left(\operatorname{Tr}(A-\hat{A})^{T}(A-\hat{A})\right)^{1 / 2}=\left(\sum_{i=1}^{m} \sum_{j=1}^{n}\left(A_{i j}-\hat{A}_{i j}\right)^{2}\right)^{1 / 2},
$$

dari persamaan (6) dibentuk formula error norm relatif, yaitu:

$$
e_{r e l}=\frac{\|A-\hat{A}\|^{2}}{\|A\|} \text {. }
$$

\section{DATA DAN METODOLOGI}

\subsection{Data Penelitian}

Data yang akan digunakan dalam penelitian ini adalah data Suhu Permukaan Laut (SPL). Data ini merupakan arsip data global bulanan yang telah direkonstruksi secara terus menerus. Rekonstruksi ini berawal dari bulan Januari 1854 sampai bulan Desember 2012, sehingga lebih dikenal dengan The Extended Reconstructed Sea Surface Temperature (ERSST). Data global ERSST ini dapat diunduh dari situs (http://www1.ncdc.noaa.gov/pub/data/cmb/ersst/v3b/netcdf) 
dengan format data digital Network Common Data Form (NetCDF). Data ini memiliki resolusi spasial $2^{\circ} \times 2^{\circ}$ dan resolusi temporal bulanan. Penelitian ini akan dibatasi penggunaan data, wilayah data dan rentang waktu. Data yang akan digunakan hanya data SPL dengan domain wilayah Indonesia $6^{\circ} \mathrm{LU}-11^{\circ} \mathrm{LS}$ dan $95^{\circ} \mathrm{BT}-141^{\circ} \mathrm{BT}$. Adapun rentang waktu yang akan diteliti yaitu selama 600 bulan berawal dari bulan Januari 1963 sampai Desember 2012. Dengan demikian, Algoritme di bawah ini memaparkan tahapan ekstraksi data SPL.

\section{Algoritme 4.1 Ekstraksi data SPL (ERSST V3B)}

1. Penentuan domain wilayah Indonesia, yaitu berada pada $6^{\circ} \mathrm{LU}-11^{\circ} \mathrm{LS}$ dan $95^{\circ} \mathrm{BT}-141^{\circ} \mathrm{BT}$.

2. Pemotongan data SPL (ERSST V3B) dari format NetCDF ke dalam grid matriks berukuran $180 \times 89$ menjadi $26 \times 13$. Jumlah pixel semula dari 16020 menjadi 338 pixel.

3. Penentuan domain rentang waktu yaitu selama 600 bulan.

4. Reshaping data yang sudah dibatasi berdasarkan poin 1, 2 dan 3 .

5. Masking darat laut untuk memisahkan unsur daratan dan lautan.

6. Penyusunan matriks data $(X)$ berdasarkan poin-poin di atas.

\subsection{Eksplorasi Data}

Eksplorasi data diawali dengan menyajikan pola data yang tersedia dalam bentuk visual. Pola ini disajikan berdasarkan grid data global dengan koordinat $180^{\circ} \mathrm{BB}-180^{\circ} \mathrm{BT}$ dan $90^{\circ} \mathrm{LU}-90^{\circ} \mathrm{LS}$, sehingga ukuran grid data dengan koordinat tersebut yaitu $190 \times 80$ pixel. Sebagai contoh pada Gambar 1(a) ditunjukkan ilustrasi visual data SPL global pada bulan Desember tahun 2012.
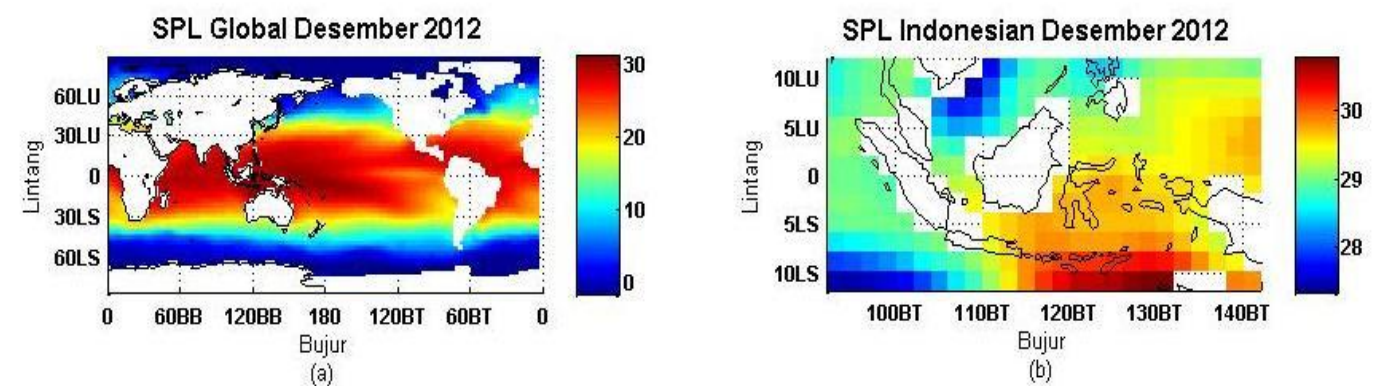

Gambar 1 Visualisasi data setelah diekstrak (a) data global SPL (b) data SPL Indonesia.

Berdasarkan Algoritme 4.1 poin 1 dan 2 dilakukan proses pemotongan data. Pemotongan data ini didasarkan pada letak geografis Indonesia yaitu berada pada koordinat $6^{\circ} \mathrm{LU}-11^{\circ} \mathrm{LS}$ dan $95^{\circ} \mathrm{BT}-141^{\circ} \mathrm{BT}$ dari grid data global yang berada pada koordinat $0^{\circ} \mathrm{BB}-360^{\circ} \mathrm{BT}$ dan $90^{\circ} \mathrm{LU}-90^{\circ} \mathrm{LS}$. Pemotongan data ini disesuaikan dengan grid data asli sehingga ukurannya menjadi $26 \times 13$ pixel. 
Gambar 1(b) menunjukkan ilustrasi visual data SPL untuk wilayah Indonesia dengan bulan dan tahun yang sama seperti Gambar 1(a).

\section{HASIL PENGHITUNGAN NUMERIK}

Pada bagian ini akan dipaparkan hasil yang diperoleh melalui analisis dan simulasi numerik. Sebagian besar dari hasil penelitian ini diperoleh dari kontribusi dataset SPL. Langkah pertama dalam mereduksi data adalah menentukan varians dari nilai eigen dan memilih komponen utama yaitu persamaan EOF baru. Persamaan baru tersebut dapat mewakili variasi dari matriks data $X$. Banyaknya komponen utama yang akan diambil, dilihat dari banyaknya persentase varians kumulatif. Jolliffe [3] memaparkan beberapa aturan dalam menentukan banyaknya komponen utama pertama, di antaranya yang mempunyai proporsi varians kumulatif lebih dari $80 \%$. Berdasarkan hal tersebut, maka dipilih empat komponen utama terbesar hasil reduksi dari 600 komponen utama yang diinisialkan dengan EOF1, EOF2, EOF3 dan EOF4. Total varians dari empat EOF tersebut sebesar 94.2\%. Angka ini lebih dari cukup untuk memuat informasi dari seluruh data SPL yang dianalisis pada wilayah Indonesia. Skor dari hasil reduksi berupa nilai eigen, varians dan total varians untuk EOF1, EOF2, EOF3 dan EOF4 secara berturut-turut ditunjukkan pada Tabel 1.

Tabel 1

Skor dari nilai eigen, varians dan total varians.

\begin{tabular}{cccc}
\hline \multirow{2}{*}{ EOF } & \multirow{2}{*}{ Nilai Eigen } & \multicolumn{2}{c}{ Persentase Varians } \\
& & Individual & Kumulatif \\
\hline \hline 1 & 308.454 & 51.409 & 51.409 \\
2 & 160.363 & 26.727 & 78.136 \\
3 & 67.132 & 11.188 & 89.325 \\
4 & 29.226 & 4.871 & 94.196 \\
\hline 5 & 10.086 & 1.681 & 95.877 \\
6 & 4.890 & 0.815 & 96.692 \\
$\ldots$ & $\ldots$ & $\ldots$ & $\ldots$ \\
600 & -2.002 & -3.336 & 100 \\
\hline
\end{tabular}

Berdasarkan Tabel 1 akan dibentuk pola spasial yang diplot setelah me-reshape kembali hasil dari mode EOF. Hasil visualisasi untuk masing-masing mode EOF ditunjukkan pada Gambar 2. 

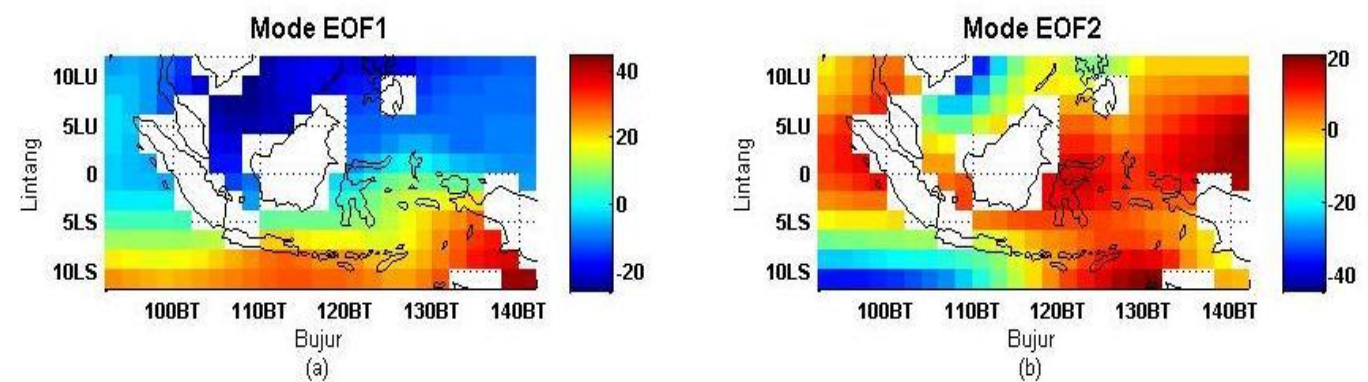

Gambar 2 Hasil analisis EOF secara spasial (a) mode spasial EOF1 (b) mode spasial EOF2.

Gambar 2(a) menunjukkan keadaan perairan Indonesia yang dihasilkan mode EOF1. Skor yang bernilai negatif pada mode ini memiliki variabilitas SPL yang berbanding terbalik dengan SPL yang bernilai positif. Mode ini juga memperlihatkan perbedaan variabilitas SPL yang mencolok di bagian utara dan selatan Indonesia. Perairan utara Indonesia memiliki variabilitas bernilai -20 sampai dengan 5, sedangkan pada perairan selatan Indonesia atau sepanjang samudera Hindia memiliki variabilitas bernilai 20 sampai dengan 40. Gambar 2(b) menunjukkan mode EOF2 yang menjelaskan keadaan perairan Indonesia didominasi oleh variabilitas positif. Variabilitas tersebut bernilai 2 sampai dengan 20 dan terlihat skor minoritasnya terdapat pada selat Sunda dengan skor antara -40 sampai dengan -20 .

Gambar 3(a) menunjukkan mode EOF3 yang menjelaskan bagian barat perairan Indonesia memiliki skor negatif yaitu -15 sampai dengan 0 , sedangkan bagian timurnya memiliki skor positif yaitu dari 5 sampai dengan 20 .

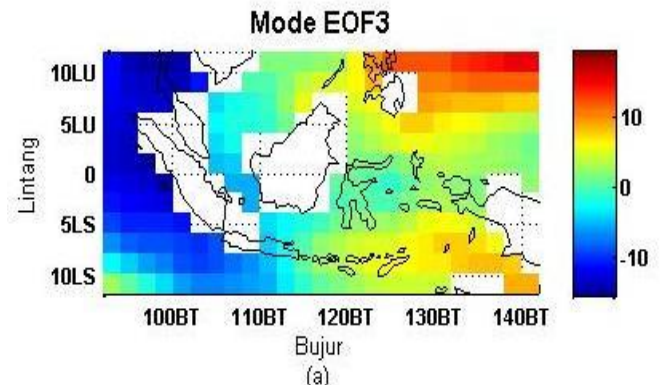

Gambar 3 Hasil analisis EOF secara spasial (a) mode spasial EOF3 (b) mode spasial EOF4.

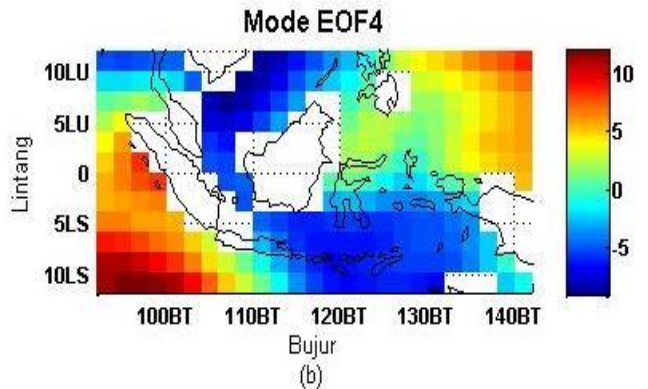

Gambar 3(b) memperlihatkan bahwa EOF4 memiliki variabilitas negatif hampir seluruh wilayah Indonesia. Variabilitas EOF4 ini memiliki skor -10 sampai dengan -2. Adapun variabilitas positifnya berada di samudera Pasifik dan samudera Hindia yang memiliki skor 2 sampai dengan 10. Pola spasial melalui empat mode EOF di atas menggambarkan fenomena laut Indonesia selama 600 bulan memiliki variabilitas SPL yang fluktuatif. Variabilitas ini ditunjukkan dengan skor positif dan negatif di setiap modenya. Jika dilihat dari pola 
temporalnya, laut Indonesia menunjukkan siklus dengan periode tahunan yang bervariasi. Pola temporal ini secara berturut-turut ditunjukkan pada Gambar 4.

Gambar 4(a) memperlihatkan mode temporal EOF1 dengan varians terbesar. Mode ini menunjukkan siklus tahunan yang diperlihatkan oleh setiap titik puncaknya. Hal ini berarti dalam kurun waktu 600 bulan, laut Indonesia digambarkan secara jelas oleh EOF1 sebesar 51.4\%. Gambar 4(b) menunjukkan mode temporal dari EOF2 yang mewakili $26.7 \%$ dari total varians. Gambar 4(c) dan 4(d) menunjukkan mode temporal EOF3 dan EOF4. Mode-mode tersebut secara berturut-turut mewakili $11.2 \%$ dan $4.9 \%$ dari total varians. Dengan demikian, variasi pertama menunjukkan pola dominan yang dapat mewakili seluruh data. Variasi yang tidak tersimpan pada EOF1 tersimpan pada EOF2 dan seterusnya, sehingga variasinya semakin lama akan semakin kecil.

Secara umum, pola temporal dapat menggambarkan siklus dari fenomena yang dijelaskan pada setiap mode EOF dan kuat lemahnya fenomena tersebut. Mode EOF dengan siklus fenomena yang kuat memberi kontribusi besar terhadap data SPL sebagai unit pengamatan demikian sebaliknya. Namun, untuk melihat kuat dan lemahnya suatu fenomena dapat diketahui dari seberapa besar nilai hampiran setiap mode terhadap data asli. Besar nilai hampiran ini dapat diketahui dengan menentukan tingkat kesalahan relatif yang disebut sebagai norm error. Dengan demikian, teknik error norm matriks digunakan untuk menentukan nilai kesalahan tersebut. Hasil yang diperoleh nilai norm error hampir mendekati nol, sehingga tingkat kesalahan relatif sangat kecil. Hal ini dapat terjadi jika mode EOF yang diambil lebih banyak.
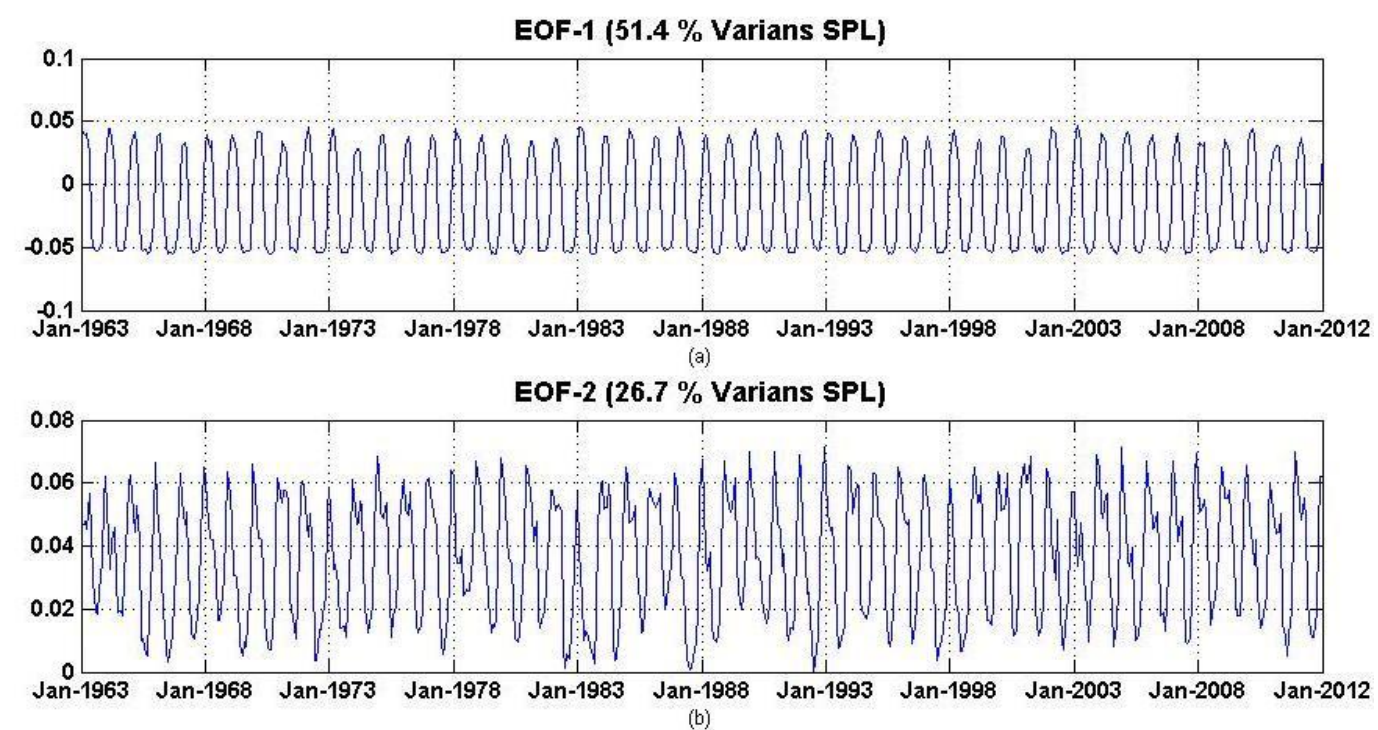

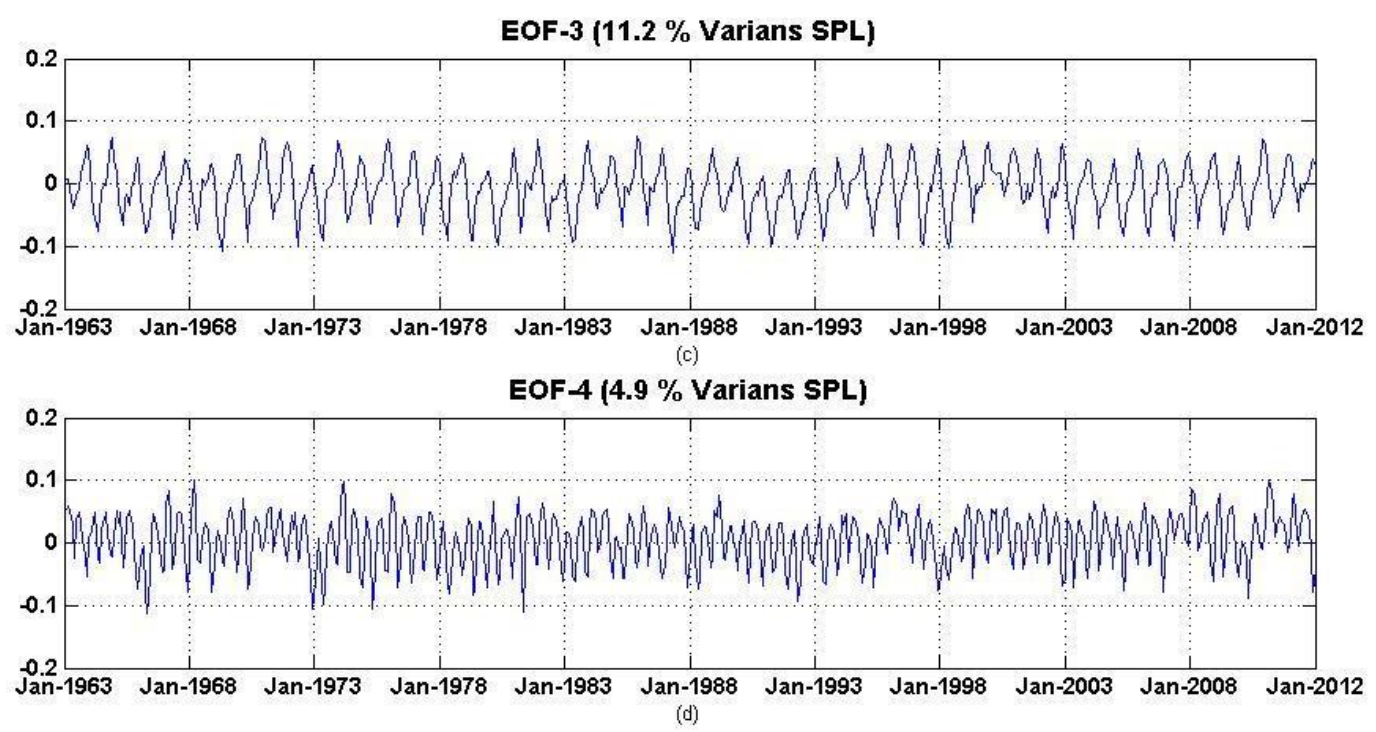

Gambar 4 Hasil analisis secara temporal (a) mode EOF1 (b) mode EOF2 (c) mode EOF3 (d) mode EOF4.

Gambar 5 memperlihatkan nilai norm error yang sangat besar ketika hanya satu mode EOF yang diambil yaitu sebesar 0.93 . Hal ini menyatakan bahwa mode EOF1 memiliki tingkat kesalahan 93\% dalam menghampiri data asli. Akan tetapi, sangatlah tidak masuk akal dengan tingkat kesalahan tersebut karena mode EOF1 mewakili $51.4 \%$ dari data asli. Namun, sangatlah dimungkinkan dengan perolehan angka tersebut karena tingkat data yang digunakan cukup besar dan tingkat kesalahannya semakin kecil dengan semakin banyak mode EOF yang digunakan.

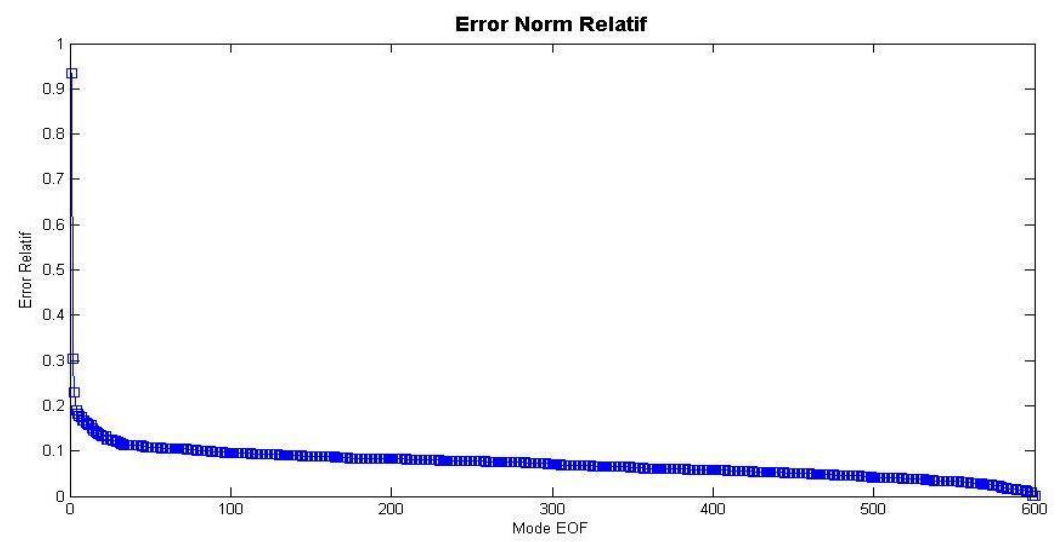

Gambar 5 Tingkat kesalahan terhadap reduksi data dengan teknik error norm matriks. 


\section{SIMPULAN}

Analisis EOF berbasis EVP terhadap dataset SPL Indonesia menghasilkan empat komponen utama (mode EOF) dengan total varians sebesar 94.2\%. Dengan demikian, diperoleh empat pola secara spasial dan temporal. Pola spasial dibentuk berdasarkan persamaan baru dari proyeksi vektor eigen terhadap asli, sedangkan pola temporal diperoleh berdasarkan vektor eigen hasil reduksi dari data asli. Adapun perolehan nilai eigen digunakan sebagai kontribusi persentase varians untuk setiap mode EOF. Empat mode EOF tersebut secara berturut-turut mewakili $51.4 \%, 26.7 \%, 11.2 \%$ dan $4.9 \%$ dari total varians. Berdasarkan hasil ini, setiap mode EOF diuji efektifitasnya dengan menentukan suatu hampiran berupa tingkat kesalahan menggunakan teknik error norm matriks. Hasil yang diperoleh dari teknik ini berupa nilai norm error yang memperlihatkan pola hubungan antara tingkat kesalahan dengan mode EOF. Dalam hal ini tingkat kesalahan menunjukkan suatu hampiran hasil reduksi terhadap data asli.

\section{DAFTAR PUSTAKA}

[1] Storch HV, Zwiers FW. 2004. "On the role of statistics in climate research". International journal of climatology. Int. J. Climatol. 24: 665-680.

[2] Hannachi A. 2004. "A primer for eof analysis of climate data”: Department of Meteorology, University of Reading, Reading RG6 6BB, U.K.

[3] Jolliffe IT. 2002. Principal component analysis. 2nd ed. New York: Springer-Verlag.

[4] Singleton T. 2008. "An empirical orthogonal function (EOF) analisys of sea surface temperature, AOSC 627": University of Maryland, College Park Department of Mathematics Applied Mathematics and Scientific Computing Program. Journal of Climate: AOSC 627.

[5] Navarra A, Simoncini V. 2010. "A guide to empirical orthogonal function for climate data analysis ": Springer.

[6] Fall. 2012. Scientific Computing \& Matrix Computations: Departments Of Mathematics and EECS , UC Berkeley.

[7] Meyer CD. 2000. "Matrix analysis \& applied linear algebra”: Siam.

[8] Golub GH \& Van L. 1996. "Matrix computation": Siam. 


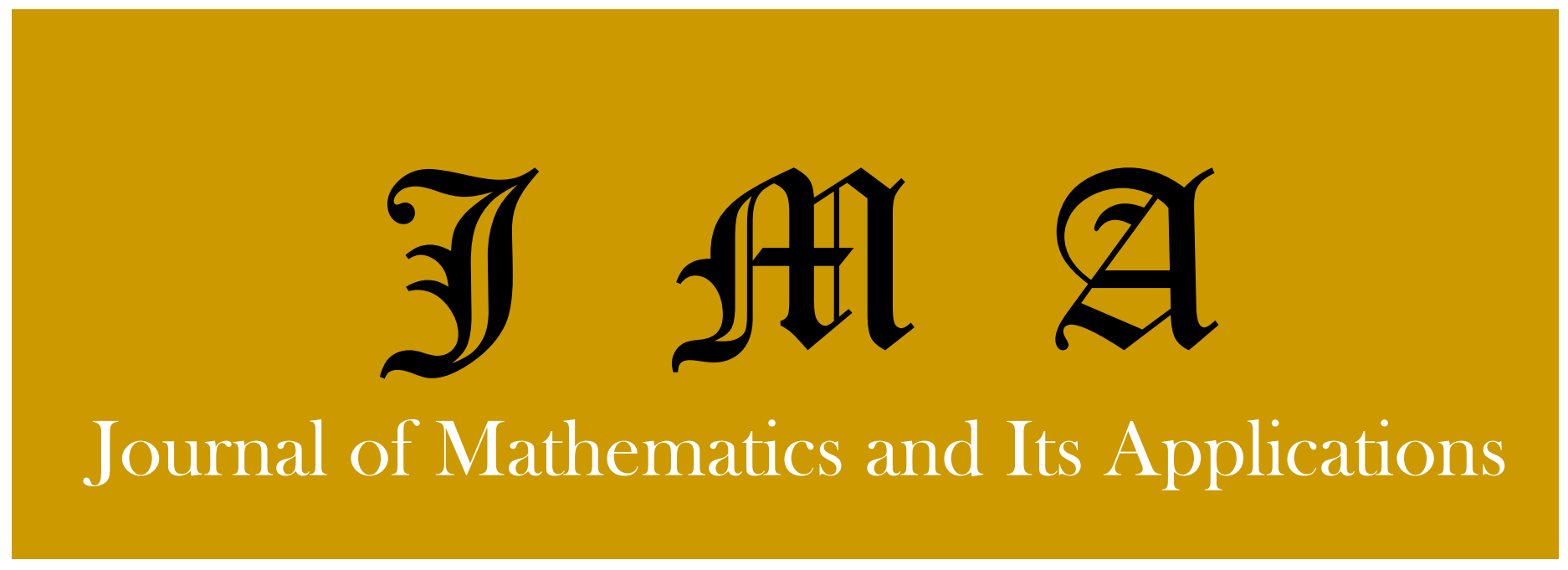

Volume 15, No. 1 July 2016

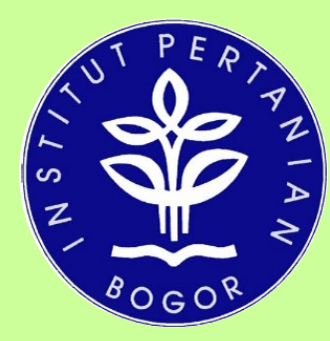

Department of Mathematics FMIPA - Institut Pertanian Bogor

JIn. Meranti, Kampus IPB Dramaga - Bogor

Phone/Fax: (0251) 8625276

E-mail: math@ipb.ac.id jma.mathipb@gmail.com
Analisis Empirical Orthogonal Function (EOF) Berbasis Eigen Value Problem (EVP) pada Dataset Suhu Permukaan Laut Indonesia

S. M. Robial, S. Nurdiati, dan A. Sopaheluwakan

Analisis Empirical Orthogonal Function (EOF) Berbasis Singular Value Decomposition (SVD) pada Data Curah Hujan Indonesia

I. L. Lestari, S. Nurdiati, dan A. Sopaheluwakan

Model Goal Programming dan Pengoptimuman Taklinear pada Penjadwalan Perawat

L. Hakim, T. Bakhtiar, dan Jaharuddin

Analisis Bifurkasi Model Leslie Gower Tipe Holling II dengan Waktu Tunda

N. F. Sahamony, P. Sianturi, dan Jaharuddin

Pendugaan Parameter dan Kekonvergenan Penduga Parameter Model Poisson Hidden Markov

M. Fikri, B. Setiawaty, dan I G. P. Purnaba

Pemodelan Poisson Hidden Markov untuk Prediksi Banyaknya Kecelakaan di Jalan Tol Jakarta-Cikampek Nurhasanah, B. Setiawaty, dan F. Bukhari 